Nadwa | Jurnal Pendidikan Islam

Vol. 11, Nomor 1, Tahun 2017

\title{
Menyelesaikan Problem Materi Belajar Bagi Anak-Anak Berkebutuhan Khusus Dengan Research And Develompment In Education
}

\author{
Lukman A. Irfan \\ Universitas Islam Indonesia (UII) Yogyakarta \\ Email: lukman.ahmadirfan@uii.ac.id
}

\begin{abstract}
Abstact
This paper discusses the problem of education for children with special needs (difable) related to problems of educational material for them, such as curriculum design, the design of textbooks, learning model, and the design of instructional media. Research conducted by the authors prove that these problems can be solved by using Method Research and Development (R \& D) in Education. Excellence of R \& D is a design study that combines theory, experts, and real conditions on the ground so that the results are very good and appropriate. $\mathrm{R} \& \mathrm{D}$ also has a very small risk in product development and learning materials for children with special needs, because product trials conducted in stages from small, medium, and then a large scale. Key Word: Education, Difable, R \& D.
\end{abstract}

\begin{abstract}
Abstrak
Paper ini membahas bertujuan menyelesaikan problem pendidikan bagi anak berkebutuhan khusus (difable) terkait dengan problem materi pendidikan bagi mereka, seperti desain kurikulum, desain buku ajar, model pembelajaran, dan desain media pembelajaran. Hasil penelitian yang dilakukan oleh penulis membuktikan bahwa problem tersebut dapat diselesaikan dengan menggunakan Metode Research and Development ( $\mathrm{R} \& \mathrm{D})$ in Education. Keunggulan $\mathrm{R}$ \& $\mathrm{D}$ di antaranya adalah desain penelitian yang menggabungkan antara teori, ahli, dan kondisi riil di lapangan sehingga hasilnya sangat bagus dan tepat. $\mathrm{R} \& \mathrm{D}$ juga mempunyai risiko yang sangat kecil dalam pengembangan produk materi belajar bagi anak-anak berkebutuhan khusus, karena uji coba produk dilakukan secara bertahap dari skala kecil, menengah, dan kemudian skala besar.
\end{abstract}

Key Word: Pendidikan, Difable, R \& D. 


\section{Pendahuluan}

Di Indonesia, permasalahan pendidikan bagi Anak Berkebutuhan Khusus (ABK) berkisar pada penyesuaian materi belajar, perbedaan kemampuan intelektual, keterbatasan waktu belajar, kemampuan guru menguasai metode pembelajaran yang efektif, kurangnya dukungan dari orang tua, kurangnya fariasi media pembelajaran. Terkait dengan problem penyesuaian materi belajar, penelitian yang dilakukan Hujair AH. Sanaky dkk. tentang Pengembangan Bahan Ajar dan Model Pembelajaran Pendidikan Agama Islam Pada Sekolah Luar Biasa Tunagrahita Ringan di Daerah Istimewa Yogyakarta membuktikan asumsi bahwa kurikulum yang dilaksanakan dalam pembelajaran PAI di SD Tuna Grahita Ringan (C) tidak sesuai dengan difabelitas yang disandang oleh siswa. ${ }^{1}$

Problem penyesuaian materi belajar ini juga terjadi di Ngawi, Malang, Bantul, Kota Yogyakarta, Gunungkidul, dan Sleman. Penelitian yang dilakukan oleh Tutik Munawaroh yang penelitian berjudul "Problematika Belajar Pendidikan Islam pada Anak Penyandang Tuna Grhaita (SLB B/C YPPLB Ngawi Kabupaten Ngawi)". Penelitian ini menghasilkan temuan bahwa problematika belajar Pendidikan Islam yang dialami siswa penyandang Tuna Grahita, di antaranya adalah penyesuaian materi. ${ }^{2}$ Begitu juga penelitian yang dilakukan Tri Mulat yang berjudul "Problematika Belajar Pendidikan Agama Islam Pada Anak Penyendang Tunagrahita di SLB PGRI Tri Mulyo Kabupaten Bantul" menghasilkan temuan bahwa problematika belajar pendidikan Islam pada siswa penyandang tunagrahita di SLB PGRI Tri Mulyo Kabupaten Bantul di antaranya materi yang terlalu berat. Penelitian lainnya, yang dilakukan oleh Dian Permatasari yang berjudul "Problematika Pembelajaran Pendidikan Agama Islam dan Solusinya pada Anak Autis di

${ }^{1}$ Hujair AH. Sanaky dkk., Pengembangan Bahan Ajar dan Model Pembelajaran Pendidikan Agama Islam Pada Sekolah Luar Biasa Tunagrahita Ringan di Daerah Istimewa Yogyakarta 2014

2 Tutik Munawaroh. "Problematika Belajar Pendidikan Agama Islam pada Anak Tunagrahita (Sekolah Luar Biasa B/C YPPLB Ngawi Kabupaten Ngawi." Skripsi. Surakarta: UMS.2009. 
Sekolah Luar Biasa (SLB) Idayu Malang” menghasilkan temuan kurangnya jam pelajaran yang disediakan untuk pendidikan agama Islam, sehingga pembelajaran tidak bisa mencapai tujuannya. ${ }^{3}$

Problem tentang materi belajar ini juga menjadi temuan penelitian Aziz Fuadi yang berjudul "Telaah Kurikulum Pendidikan Agama Islam Pada Sekolah Luar Biasa", menemukan bahwa secara kualitatif kurikulum PAI (SK-KD) yang dikeluarkan BNSP (Badan Nasional Standar Pendidikan), ditinjau dari aspek Psikologis hanya sesuai untuk jenis Tuna netra (A) dan tunadaksa (D), belum sesuai/kurang relevan untuk kondisi ketunaan yang lain, seperti: jurusan B, C, CI, E, G. ${ }^{4}$ Siti Munfadilah (2008) dalam penelitiannnya yang berjudul "Manajemen Pendidikan Agama Islam Bagi Anak berkebutuhan Khusus" membahas masalah perencanaan manajemen pembelajaran PAI di SLB Negeri I Yogyakarta pada tahun 2008. Hasil temuannya menyebutkan bahwa materi pembelajaran Pendidikan Agama Islam disamaratakan antara ABK dengan semua jenis ketunaan dan materi yang ditetapkan dalam kurikulum masih terlalu umum dan belum sesuai dengan anak berkebutuhan khusus. ${ }^{5}$

Problem materi belajar Pendidikan Agama Islam pada dasarnya dapat diselesaikan dengan menggunakan Metode Penelitian Research and Development in Education. Metode penelitian ini menurut penulis sangat tepat karena, sebagaimana dikatakan Borg \& Gall bahwa Research and Development in Education bertujuan untuk merancang produk dan prosedur baru yang selanjutnya secara sistematis diuji di lapangan, dievaluasi dan disempurnakan hingga memenuhi kriteria efektif dan

${ }^{3}$ Permatasari. Dian, "Problematika Pembelajaran Pendidikan Agama Islam dan Solusinya pada Anak Autis di Sekolah Luar Biasa (SLB) Idayu Malang”. Skripsi. Malang: Fakultas Tarbiyah UIN Malang.2009.

${ }^{4}$ Aziz Fuadi. . "Telaah Kurikulum Pendidikan Agama Islam Pada Sekolah Luar Biasa“. Tesis. Yogyakarta: IAIN Sunan Kalijaga,2011

${ }^{5}$ Siti Munfadilah, "Manajemen Pendidikan Agama Islam Bagi anak berkebutuhan Khusus". Tesis. Yogyakarta: PPs Universitas Islam Negeri.2008. 
bermutu. ${ }^{6}$ Hal ini juga diungkapkan oleh Gay bahwa research and development adalah "The major purpose of $R \& D$ efforts is not to formulate or test theory but to develop effective products for use in school. Products produced by $R \& D$ efforts include: teacher training materials, learning materials, sets of behavioral objectives, media material, and management system". 7

Makalah ini akan mendeskripsikan urgensi penerapan metode Research and Development dalam Mengatasi Problem Materi Pembelajaran Anak Berkebutuhan Khusus. Problem materi yang dimaksud dalam paper ini meliputi desain kurikulum, desain buku ajar, model pembelajaran, dan desain media pembelajaran.

\section{Pendidikan Anak Berkebutuhan Khusus di Indonesia}

"Seorang anak yang berkebutuhan khusus" atau sering disebut "anak berkelainan" didefinisikan sebagai "seseorang yang memiliki performansi fisik, mental dan perilaku yang secara substansial berdeviasi atau menyimpang dari yang normal, baik lebih tinggi atau lebih rendah. Secara lebih spesifik, anak berkebutuhan khusus meliputi mereka yang tuli, buta, mempunyai gangguan bicara,cacat tubuh, retardasi mental, gangguan emosional. Juga anak-anak yang berbakat dengan inteligensi yang tinggi karena memerlukan penanganan dari tenaga profesional.

Di Indonesia, pendidikan anak berkebutuhan khusus atau anak luar biasa adalah sebagai pemberian hak asasi manusia sesuai bunyi Undang- Undang RI No. 4 Tahun 1997 tentang penyandang cacat. Bab 1 pasal 1 ayat 3 "kesamaan kesempatan adalah keadaan yang memberikan peluang kepada penyandang cacat (fisik, mental, fisik dan mental, ayat 1 a b c ), untuk mendapatkan kesempatan yang sama dalam segala aspek kehidupan dan penghidupan". PP No.43 Tahun 1998 Bab II pasal 6 "Kesamaan kesempatan bagi penyandang cacat diarahkan untuk mewujudkan kesamaan kedudukan, hak,

${ }^{6}$ Borg, R. Walter dan Gall, Meredith D. Educational Reseach: An Introduction, Fifth Edition. New York: Longman.1989. 
kewajiban dan peran penyandang cacat, agar dapat berperan dan berintegrasi secara total sesuai dengan kemampuannya dalam segala aspek kehidupan dan penghidupan". Lebih rinci pada pasal 23 tentang kesamaan kesempatan dalam pendidikan dinyatakan: "Setiap penyandang caca memiliki kesempatan dan perlakuan yang sama dalam memperoleh pendidikan pada satuan, jalur, jenis dan jenjang pendidikan sesuai dengan jenis dan kecacatannya". Bahkan, dalam pasal 24 ayat (1) dinyatakan "Setiap penyelenggara satuan pendidikan bertanggung jawab atas pemberian kesempatan dan perlakuan yang sama kepada penyandang cacat untuk memperoleh pendidikan"8

Pendidikan berkebutuhan khusus didefinisikan dalam konteks anak-anak yang memiliki kualifikasi untuk menerima layanan khusus. Anak yang berkebutuhan pendidikan khusus: cacat penglihatan (tunanetra), cacat pendengaran (tunarungu), cacat fisik (tunadaksa), cacat/keterbelakangan mental (tunagrahita), kesulitan penyesuaian diri (maladjustment/tunalaras) dan kesulitan belajar.

Dewasa ini, anak- anak yang berkebutuhan khusus meliputi mereka penyandang cacat/keterbelakangan mental (tunagrahita), berkesulitan komunikasi, berkesulitan belajar, penyimpangan perilaku, cacat penglihatan (tunanetra), cacat pendengaran (tunarungu), cacat fisik dan kesehatan (tuna daksa), berbakat dan kreatif, atau suatu kombinasi dari cacat ganda dan/atau talenta khusus.

\section{Prosedur R \& D Versi Borg dan Gall}

Langkah-langkah Research and Development yang digagas oleh Borg \& Gall ${ }^{9}$ dalam bukunya Educational Research: An Introduction yang meliputi sepuluh langkah:

\section{Studi Pendahuluan}

Pertanyaan pertama saat akan melakuan penelitian dan pengembangan produk adalah apakah produk yang akan dibuat mempunyai makna dalam perkembangan pendidikan? Secara teknis, langkah studi pendahuluan

${ }^{8}$ Puskur PLB. Kurikulum SLB dan Standar Isi. Jakarta: Depdiknas. 2006.

${ }^{9}$ Borg, R. Walter dan Gall, Meredith D. Educational Reseach:... 
dimulai dengan studi literatur. Untuk melakukan studi literatur, maka objek penelitian harus diurai terlebih dahulu. Riset skala kecil dalam konteks penelitian dan pengembangan produk model pelatihan ini dapat difokuskan pada komparasi antara kerangka teori yang didapat dari studi literatur dengan kondisi riil di lapangan.

\section{Merencanakan Penelitian}

Setelah melakukan studi pendahuluan, langkah selanjutnya adalah merencanakan penelitian. Perencaaan penelitian R \& D meliputi: (1) merumuskan tujuan penelitian; memperkirakan dana, tenaga dan waktu; (3) merumuskan kualifikasi peneliti dan bentuk-bentuk partisipasinya dalam penelitian. Borg dan Gall (1989) mengungkapkan bahwa perencanaan penting dalam rangka mengantisipasi kebutuhan material, bantuan ahli, dan uji lapangan.

\section{a. Merumuskan tujuan penelitian}

Secara operasional, tujuan penelitian dapat dirumuskan dari masalah yang menjadi sumber munculnya ada dan mengapa penelitin dilakukan. Sumber muncul masalah penelitian adalah karena adanya kesejangan antara idealita (das sein) dan realita (das sollen). Dalam pendekatan $\mathrm{R} \& \mathrm{D}$ Pendidikan, sumber masalah penelitian dipetakan menjadi 4 bidang yang berakar pada mencari solusi pemecahan problem pendidikan dengan mencari dan atau mengembangkan model. Keempat bidang tersebut yaitu: (1) Organisasi dan Menajemen Pendidikan; (2) Pembiayaan Pendidikan; Mutu/Pembelajaran; dan (4) Kinerja dan Manajemen Guru.

\section{b. Memperkirakan Dana, Tenaga dan Waktu}

Memperkirakan Dana, Tenaga dan Waktu adalah terkait dengan manajemen penelitian, artinya keberhasilan dan kegagalan penelitian. Oleh karenanya sangat penting untuk membuat estimasi dana, kebutuhan tenaga dan membuat time schedule. Untuk estimasi kebutuhan dana dalam penelitian, maka peneliti perlu membuat daftar kebutuhan, termasuk kebutuhan tenaga tambahan dan pendek-panjangnya rentang waktu yang akan dibutuhkan dalam penelitian. Membuat Daftar kebutuhan berarti 
mengurai perjalanan penelitian tahap demi tahap, mulai dari kebutuhan kertas dan tinta hingga untuk deseminasi dan distribusi produk dan implementasi tahap akhir.

\section{c. Merumuskan kualifikasi peneliti dan bentuk-bentuk partisipasinya dalam penelitian}

Pada dasarnya merumuskan kualifikasi peneliti ini adalah untuk mengatasi keterbatasan peneliti (utama). Seorang peneliti sangat mungkin mempunyai keterbatasan pada hal-hal tertentu, umpamanya keterbatasan dalam uji data statistik, pengambilan data dan lain-lain. Secara praktis, untuk membuat kualifikasi peneliti dan bentuk partisipasinya harus dibuat terlebih dahulu kebutuhan penelitian yang harus minta bantuan orang lain. Umpamamnya untuk pengembilan data, skoring data atau analisis data statistik.

\section{Pengembangan Desain}

Langkah-langkah dalam mengembangkan desain meliputi: (1) Menentukan desain produk yang akan dikembangkan (desain hipotetik); (2) menentukan sarana dan prasarana penelitian yang dibutuhkan selama proses penelitian dan pengembangan; (3) menentukan tahap-tahap pelaksanaan uji desain di lapangan; (4) menentukan deskripsi tugas pihakpihak yang terlibat dalam penelitian.

a. Menentukan Desain Produk yang akan dikembangkan (Desain Konseptual/Desain Hipotetik) Dalam menyusun desain model dilakukan berdasarkan hasil studi pendahuluan. Desain model yang disusun dalam penelitian ini menerapkan pendekatan sistem pembelajaran dengan memperhatikan delapan komponen. Secara garis besar kedelapan komponen tersebut tercakup dalam tiga tahap yaitu: tahap perencanaan, tahap pelaksanaan, dan tahap evaluasi. Pada tahap perencanaan terdiri dari: (1) menentukan tujuan pelatihan, (2) menentukan mata pelajaran dan analisis tujuan pelatihan, (3) menentukan kelompok calon peserta dengan mengidentifikasi kemampuan awal calon peserta pelatihan yang akan menerima pelajaran, dan (4) merumuskan tujuan atau tingkat hasil belajar 
yang ingin dicapai dengan menentukan kawasan belajar tertentu dari setiap mata pelajaran. Tahap pelaksanaan, terdiri dari; (1) menentukan tes awal (pre-test) dari setiap mata pelajaran dengan mendasarkan pada tingkat hasil belajar yang telah ditentukan, (2) pengembangan materi pelajaran untuk setiap mata pelajaran, dan (3) pengembangan strategi pembelajaran. Sedang pada tahap evaluasi menentukan 1 komponen, yaitu tes akhir (posttest). Tes ini bertujuan tujuan untuk mengetahui manfaat dari pelatihan yang telah diikuti peserta.

\section{b. Aspek Desain Produk}

Selanjutnya, dalam mendesain produk $\mathrm{R} \& \mathrm{D}$ harus memperhatikan hal-hal berikut:

1) Kejelasan tujuan pelatihan.

2) Relevansi tujuan training dengan kebutuhan remaja.

3) Ketepatan penggunaan multimedia yang sesuai dengan tujuan dan materi pembelajaran.

4) Kesesuaian materi, pemilihan multimedia dan evaluasi (latihan, test, kunci jawaban) dengan tujuan pembelajaran.

5) Sistematika yang runut, logis, dan jelas.

6) Interaktivitas.

7) Penumbuhan motivasi belajar.

8) Kontekstualitas.

9) Kelengkapan dan kualitas bahan bantuan belajar.

10) Kejelasan uraian materi, pembahasan, contoh, simulasi, latihan.

11) Konsistensi evaluasi dengan tujuan pembelajaran.

12) Relevansi dan konsistensi alat evaluasi.

13) Pemberian umpan balik terhadap latihan dan hasil evaluasi.

\section{c. Aspek Rekayasa Perangkat Lunak dalam} Pemanfaatan Bahan dan Strategi

Dalam mendesain produk, pemanfaatan bahan dan strategi model harus memperhatikan hal-hal berikut:

1) Efektif dan efisien dalam pengembangan maupun penggunaan multimedia pembelajaran.

2) Reliabilitas (kehandalan). 
3) Maintainabilitas (dapat dipelihara/dikelola dengan mudah).

4) Usabilitas (mudah digunakan dan sederhana dalam pengoperasiannya).

5) Ketepatan pemilihan jenis aplikasi/software/tool untuk pengembangan.

6) Kompatibilitas (multimedia pembelajaran dapat diinstalasi/dijalankan di berbagai hardware dan software yang ada).

7) Pemaketan program multimedia pembelajaran terpadu dan mudah dalam eksekusi.

8) Dokumentasi program multimedia pembelajaran yang lengkap meliputi: petunjuk instalasi (jelas, singkat, lengkap), trouble shooting (jelas, terstruktur, dan antisipatif), desain program (jelas dan menggambarkan alur kerja program).

\section{d. Aspek Komunikasi Visual}

Selain harus memperhatikan aspek-aspek di atas, strategi training harus dengan memperhatikan hal-hal berikut:

1) Komunikatif: visualisasi mendukung materi ajar, agar mudah dicerna oleh peserta.

2) Kreatif: visualisasi diharapkan disajikan secara unik dan tidak klise (sering digunakan), agar menarik perhatian.

3) Sederhana: visualisasi tidak rumit, agar tidak mengurangi kejelasan isi materi ajar dan mudah diingat.

4) Unity: menggunakan bahasa visual yang harmonis, utuh, dan senada, agar materi ajar dipersepsi secara utuh (komprehensif).

5) Penggambaran objek dalam bentuk image (citra) yang representative.

6) Pemilihan warna yang sesuai, agar mendukung kesesuaian antara konsep kreatif dan topik yang dipilih.

7) Tipografi (font dan susunan huruf), untuk memvisualisasikan bahasa verbal agar mendukung isi pesan, baik secara fungsi keterbacaan maupun fungsi psikologisnya. 
8) Tata letak (lay-out): peletakan dan susunan unsurunsur visual terkendali dengan baik, agar memperjelas peran dan hirarki masing-masing unsur tersebut.

9) Unsur visual bergerak (animasi dan/atau movie), animasi dapat dimanfaatkan untuk mensimulasikan materi ajar dan video untuk mengilustrasikan materi secara nyata.

10) Navigasi (icon) yang familiar dan konsisten agar efektif dalam penggunaannya.

e. Menentukan sarana dan prasarana penelitian yang dibutuhkan selama proses penelitian dan pengembangan

Menentukan sarana dan prasarana bertujuan untuk kelancaran penelitian yang akan dilakukan. Semua direncanakan secara detail untuk menjamin kelancaran penelitian. Sarana dan Prasarana penelitian dalam konteks ini dapat berupa program (sofware) dan perangkat keras (hardware). Termasuk dalam kategori sarana-prasarana terpenting adalah instrumen penelitian untuk memperoleh umpan balik dari pemakai produk dan ahli (untuk mengevaluasi validitas produk dan validitas konstruk).

\section{f. Menentukan tahap-tahap pelaksanaan uji desain di} lapangan

Tatap-tahap pelaksanaan uji desain di lapangan meliputi: Kesiapan model, personel, tempat, subjek penelitian, instrumen evaluasi. Prinsip terpenting dari tahapan uji terbatas ini adalah adanya umpan balik dari pemakai produk.

g. Menentukan deskripsi tugas pihak-pihak yang terlibat dalam penelitian

Deskripsi tugas pihak-pihak yang terlibat dalam penelitian ini adalah prosedur kerja dari pihak-pihak yang terlibat dalam penelitian (pengembang, peneliti, peserta training/subjek, dan ahli). 


\section{Preliminary Field Test}

Tujuan dari langkah ini adalah untuk memperoleh deskripsi latar (setting) penerapan atau kelayakan suatu produk. Hal terpenting dari langkah ini adalah didapatnya umpan balik dari produk yang sudah didesain untuk mendesain ulang produk menjadi lebih baik dari sebelumnya. Langkah ini meliputi: (1) melakukan uji lapangan awal terhadap desain produk; (2) bersifat terbatas, baik substansi desain maupun pihak-pihak yang terlibat; (3) uji lapangan awal dilakukan secara berulang-ulang sehingga diperoleh desain layak, baik substansi maupun metodologi.

Uji yang pertama ini bersifat terbatas untuk meminimalkan resiko dari pengujian tersebut. Dari uji awal ini didapatkan kelemahan dan kelebihan dari desain yang sudah ada tersebut. Langkah pengujian ini dapat dilakukan di depan 4 sampai 8 partisipan (subjek dari model yang dikembangkan, yaitu remaja).

\section{Revisi Hasil Uji Lapangan Terbatas}

Langkah ini merupakan langkah lanjutan dari langkah sebelumnya Langkah ini pada intinya bertujuan untuk merevisi produk berdasarkan hasil uji lapangan terbatas. Data yang diperoleh dari hasil uji lapangan terbatas dikumpulkan dan kemudian dianalisis. Hasil analisis tersebut digunakan oleh pengembang untuk merevisi produk yang dikembangkan.

\section{Main Field Test}

Langkah merupakan uji produk secara lebih luas, biasanya disebut uji coba utama. Tujuan dari tahap ini adalah menentukan apakah suatu produk yang hendak dikembangkan benar-benar telah menunjukkan suatu performansi sebagaimana yang diharapkan. Langkah ini meliputi (1) melakukan uji efektivitas desain produk; (2) uji efektivitas desain, (3) Hasil uji lapangan adalah diperoleh desain yang efektif, baik dari sisi substansi maupun metodologi. 


\section{Revisi Hasil Uji Lapangan Lebih Luas}

Langkah ini merupakan perbaikan kedua setelah dilakukan uji lapangan yang lebih luas dari uji lapangan yang pertama. Bahan revisi tahap ini adalah hasil uji coba utama. Hasil revisi tahap ini adalah produk yang siap divalidasi.

\section{Uji Kelayakan (Operational Field Test).}

Langkah ini dilakukan dengan skala besar: (1) melakukan uji efektivitas dan adaptabilitas desain produk; (2) uji efektivitas dan adabtabilitas desain melibatkan para calon pemakai produk; (3) hasil uji lapangan adalah diperoleh model desain yang siap diterapkan, baik dari sisi substansi maupun metodologi. Tujuan utama dari tahap ini adalah untuk menentukan apakah suatu produk yang dikembangkan tersebut benar-benar siap pakai oleh sasaaran produk tanpa melibatkan kehadiran peneliti atau pengembang produk. Pada umumnya tahap ini disebut tahap validasi model.

\section{Revisi Final Hasil Uji Kelayakan}

Langkah ini akan lebih menyempurnakan produk yang sedang dikembangkan. Sebagaimana dilakukan pada langkah-langkah sebelumnya, yaitu hasil uji dapat dijadikan umpan balik untuk perbaikan dan penyempurnaan produk yang dikembangkan.

\section{Desiminasi dan Implementasi Produk Akhir}

Hasil Penelitian ini sebisa mungkin diringkas dalam bentuk artikel yang akan dikirimkan ke Jurnal Ilmiah ataupun multimedia massa. Hal ini untuk mempublikasikan hasil penelitian tersebut. Hasil penelitian yang telah dilakukan dapat juga dipublikasikan melalui forum-forum ilmiah. Sementara itu, produk dari penelitian yang telah dilakukan dapat didistribusikan melalui perpustakaan, dinasdinas terkait ataupun melalui toko buku. Yang terpenting dalam mendistribusikan produk ini adalah produk harus dilakukan setelah melalui quality control.

Kesepuluh langkah tersebut dapat disederhanakan sebagaimana bagan alur dalam gambar 3 berikut: 


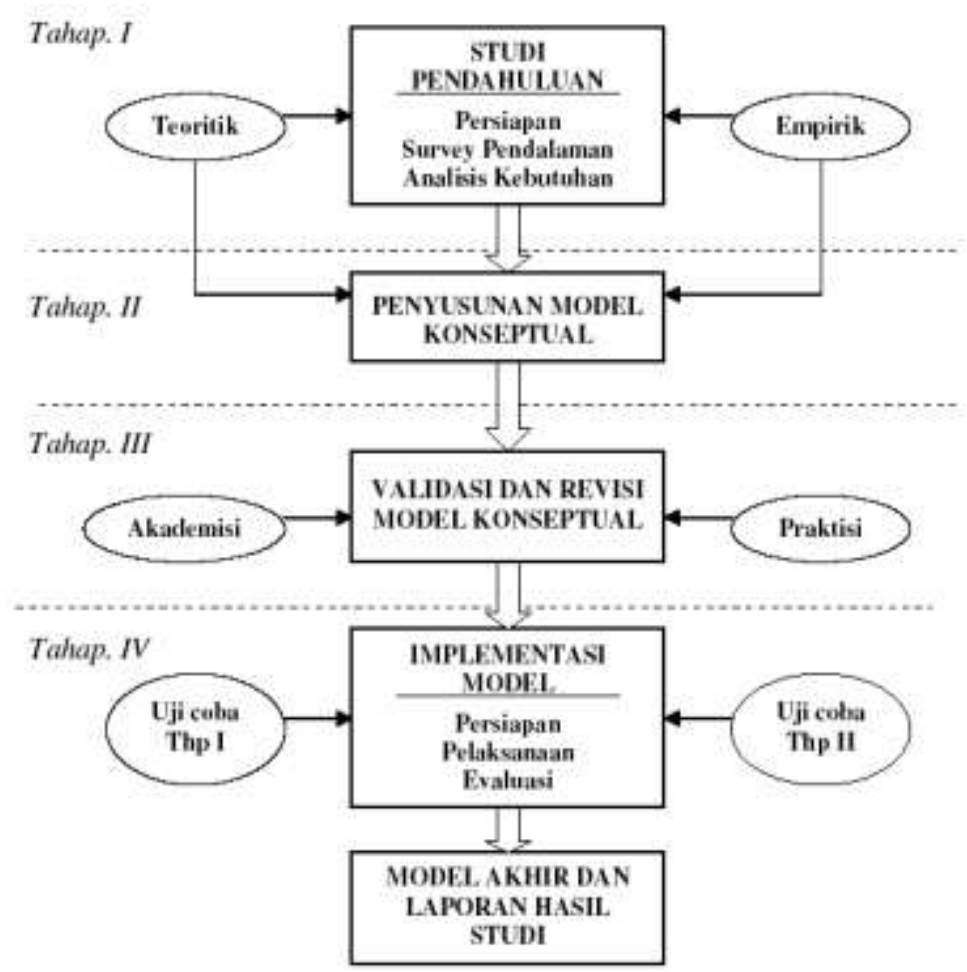

Gambar 1.

Bagan Alur Penyederhanaan 10 Langkah R \& D

\section{Pembahasan}

Pilihan Menggunakan Metode Research and Development dalam menyelesaikan problem materi untuk pendidikan anak berkebutuhan khusus didasari beberapa keunggulannya yang menjadi pertimbangan, yaitu:

1. Research and Development in Education bertujuan untuk merancang produk dan prosedur baru yang selanjutnya secara sistematis diuji di lapangan, dievaluasi dan disempurnakan hingga memenuhi kriteria efektif dan bermutu $^{10}$

${ }^{10}$ Borg, R. Walter dan Gall, Meredith D. Educational Reseach... 
2. Merupakan metode penelitian yang digunakan untuk menemukan, mengembangkan, dan menvalidasi produproduk yang digunakan dalam pendidikan dan pembelajaran 11 .

3. Untuk mengembangkan produk yang efektif di sekolah ${ }^{12}$

4. Merupakan "jembatan" antara penelitian dasar dan penelitian terapan ${ }^{13}$

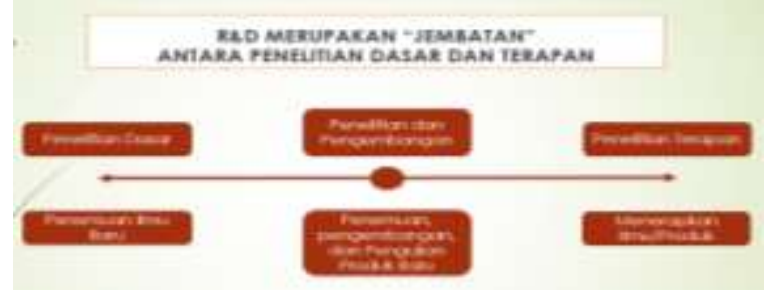

Gambar 2.

R \& D sebagai jembatan penelitian dasar dan terapan

5. Bersifat longitudinal (beberapa tahap): untuk analisis kebutuhan dan mampu menghasilkan produk hipotetik digunakan penelitian dasar, untuk menguji produk hipotetik digunakan eksperimen atau action research. ${ }^{14}$

6. Uji dilakukan secara bertahap dari skala kecil, menengah, dan kemudian skala besar, sehingga terhindar dari kerugian yang besar.

7. Desiminasi dan Implementasi Produk Akhir bisa diterapkan apabila sudah betul-betul teruji kelayakannya.

Dari pembahasan pembahasan hasil penelitian dapat disimpulkan bahwa Modul PAI untuk kelas 1 SD Tuna Ghrahita Ringan yang layak dipakai dalam pembelajaran adalah bahan ajar yang berprinsip; (a) dari yang mudah ke yang sulit, dari yang kongkrit ke abstrak, dari yang sederhana ke yang komplek, (b) sesuai dengan kemampuan dan karakteristik siswa; (c) menekankan keterampilan fungsional dengan kondisinya; (d) menarik dan membantu penyajian. Hasil research and

11 Sugiyono. . Metode Penelitian Pendidikan Pendekatan Kuantitatif, Kualitatif, dan R\&D. Bandung: Alfabeta.2014

${ }^{12}$ Gay, LR. 1981. Educational Reseach...

${ }^{13}$ Sugiyono. . Metode Penelitian Pendidikan Pendekatan ...

${ }^{14}$ Sugiyono. . Metode Penelitian Pendidikan Pendekatan ... 
development in education menunjukkan bahwa modul yang dikembangkan: (1) Mempunyai Kelayakan Isi dengan kategori Baik; (2) Dari aspek bahasa dan gambar juga menunjukkan hasil Baik; (3) Dilihat dari aspek penyajian menunjukkan hasil Baik; (4) Dari aspek penyajian termasuk kategori "Sangat baik" karena memiliki keseimbangan teks dengan gambar, ukuran gambar, penggunaan huruf, sampul modul yang menarik, sehingga mempermudah siswa memahami materi dalam modul.

\section{Kesimpulan}

Permasalahan penyesuaian materi belajar ini dapat diselesaikan dengan menggunakan Metode Research and Development ( $\mathrm{R} \& \mathrm{D})$ in Education. $\mathrm{R} \& \mathrm{D}$ ini teruji secara efektif untuk merancang produk materi belajar bagi anak-nak berkebutuhan khusus. Keunggulan R \& D di antaranya adalah desain penelitian yang menggabungkan antara teori, ahli, dan kondisi riil di lapangan sehingga hasilnya sangat bagus dan tepat. Keunggulan lainnya adalah mempunyai risiko sangat kecil dalam pengembangan produk materi belajar bagi anak-anak berkebutuhan khusus, karena uji coba produk dilakukan secara bertahap dari skala kecil, menengah, dan kemudian skala besar. 


\section{Daftar Pustaka}

Aziz Fuadi. 2011. "Telaah Kurikulum Pendidikan Agama Islam Pada Sekolah Luar Biasa". Tesis. Yogyakarta: IAIN Sunan Kalijaga.

Borg, R. Walter dan Gall, Meredith D. 1989. Educational Reseach: An Introduction, Fifth Edition. New York: Longman.

BSNP. 2006. Standar Kompetensi dan Kompetensi dasar PAI, Jakarta: Depdiknas.

Hujair AH. Sanaky dkk.2014, Pengembangan Bahan Ajar dan Model Pembelajaran Pendidikan Agama Islam Pada Sekolah Luar Biasa Tunagrahita Ringan di Daerah Istimewa Yogyakarta

Permatasari. Dian, 2009. "Problematika Pembelajaran Pendidikan Agama Islam dan Solusinya pada Anak Autis di Sekolah Luar Biasa (SLB) Idayu Malang”. Skripsi. Malang: Fakultas Tarbiyah UIN Malang.

Endang Poerwanti, dkk. 2008. Asesmen Pembelajaran SLB, Jakarta: Direktorat Jenderal Pendidikan Tinggi, Departemen Pendidikan Nasional.

Gay, LR. 1981. Educational Reseach. Ohio: Charles E. Memil Publishing co.

Idrus, Muhammad. 2009. Metode Penelitian Sosial Pendekatan Kualitatif dan Kuantitatif Edisi Kedua. Jakarta: Penerbit Erlangga.

Mangunsong, F. 1998. Psikologi dan Pendidikan Anak Luar Biasa. LPSP3UI

Munandar, Utami. 2009. Pengembangan Kreativitas Anak Berbakat. Jakarta: Penerbit Rineka Cipta bekerjasama dengan Pusat Perbukuan Depdiknas. 
Munfadilah. Siti, 2008. "Manajemen Pendidikan Agama Islam Bagi anak berkebutuhan Khusus". Tesis. Yogyakarta: PPs Universitas Islam Negeri.

Puskur PLB. 2006. Kurikulum SLB dan Standar Isi. Jakarta: Depdiknas.

Soemantri, T.S. 2007. Psikologi Anak Luar Biasa. Cetakan II. Bandung: Refika Aditama.

Sugiyono. 2014. Metode Penelitian Pendidikan Pendekatan Kuantitatif, Kualitatif, dan R\&D. Bandung: Alfabeta.

Tri Mulat. 2011. "Problematika Belajar Pendidikan Agama Islam Pada Anak Penyendang Tunagrahita di SLB PGRI Tri Mulyo Kabupaten Bantul." Skripsi. Yogyakarta: Fakultas Tarbiyah UIN Sunan Kalijaga Yogyarta.

Tumanggor, Rusmini. 2009. Pendidikan Agama di SLB. Jakarta: Ditpais Depag Republik Indonesia.

Tutik Munawaroh. 2009. "Problematika Belajar Pendidikan Agama Islam pada Anak Tunagrahita (Sekolah Luar Biasa B/C YPPLB Ngawi Kabupaten Ngawi." Skripsi. Surakarta: UMS. 